\title{
Research on Practical Teaching Reform of Tourism Management Major on the Basis of Promotion of Vocational Ability
}

\author{
Chunli Lv \\ Department of Tourist Management \\ Yantai Nanshan University \\ Yantai, China
}

\author{
Xinqi Ding \\ Department of Tourist Management \\ Yantai Nanshan University \\ Yantai, China
}

\begin{abstract}
Vocational ability is the practical requirement of tourism industry for tourism talents. The purpose of practical teaching reform of tourism management major is to promote vocational ability. On the basis of analyzing vocational ability that university graduates of applied tourism management should have, anew understand the concept of "vocational education", change thoughts, connect professional standard and industrial standard, strengthen the construction of practical teaching system, teachers and practice base on and off campus, reform evaluation system of practical teaching, comprehensively improve vocational ability of students, enhance employment competitiveness of students, and then promote industrial and professional development.
\end{abstract}

Keywords-vocational ability; practical teaching; applied undergraduate; tourism management

\section{INTRODUCTION}

Higher education in tourism is a vocational professional education and has very strong applicability, professionalism and practicality. Applied undergraduate shall take employment as the orientation and pay attention to cultivate students' professional consciousness, occupational habit and vocational ability. While the traditional teaching model "pays attention to theory and attaches less importance to practice". It is very difficult for students who receive this kind of education to adapt to industry environment. Looking from the feedback situation that many tourism enterprises use talented people, compared with vocational college students and secondary specialized school students, undergraduate students may have more profound theoretical knowledge. But their operational ability and ability in solving practical problems are inferior to vocational college students. This kind of "mismatch between supply and demand" reflects disjunction between higher education in tourism and sector demand on vocational ability and reflects that students lack scientific and systematic vocational ability training on school days. Therefore, it has important practical significance on promoting the development of tourism industry to strengthen the cultivation of students' vocational ability and bring up a batch of high quality applied talents to adapt to the development of tourism industry. In the cultivation of vocational ability, practical teaching plays a very important role that theory teaching cannot replace.

\section{ANALYSIS ON VOCATIONAL ABILITY OF APPLIED TOURISM MANAGEMENT UNDERGRADUATES}

\section{A. Concept of Vocational Ability}

Vocational ability is the necessary ability for people to work on occupational activities. It is the integration of knowledge, attitude and skill to carry out occupational activities, including basic vocational abilities and comprehensive vocational abilities. Schools take on the job of cultivation of students' basic vocational abilities. It plays a dominant role in students' personal future development.

\section{B. Analysis on Vocational Ability of Applied Tourism Management Undergraduates}

At present, there is no single standard for vocational ability that applied tourism management undergraduates shall have. It is widely believed that they shall have the ability of four levels: The first is basic quality of industry, such as language expression and communication ability, artistic appreciation, etiquette cultivation and service awareness. The second is service skill on the post, such as tour guide skill, planning skill and hotel service skill. The third is comprehensive ability, such as the ability to obtain information, competitive ability and teamwork ability. The fourth is the ability of innovation and development, such as learning ability, public relation ability, ability to organize and coordinate, innovation and entrepreneurship ability and ability of sustainable development.

\section{RELATIONSHIP BETWEEN THE PROMOTION OF VOCATIONAL ABILITY AND PRACTICAL TEACHING}

\section{A. Practical Requirements of Tourism Industry for Talents in Tourism Management Major}

Compared with other industries, one of the outstanding features of tourism industry is the combination of theory and practice. Sometimes practice is even more important than theory. It is in great need of applied talents who understand theory and can operate. Middle and senior managers in tourism industry must be familiar with basic business or start from the basic level. It decides that it is impossible for schools to deliver senior management personnel for the industry directly. 
They shall deliver graduates with relatively strong professional adaptability, skilled business and basic management ability. In order to achieve the training goal, it can't do without practical teaching.

At present, the practical teaching in colleges related to tourism in our country can be roughly divided into three layers and four directions. The three layers are operational, analytical and investigative from low to high; the four directions are travel agency, hotel management, development of tourism resources and scenic area management, macro management of tourism industry. On operational level, students shall master various basic operational skills and improve operational ability; on the level of analysis, students shall master the thinking skills to find problems and carry out preliminary generalization and summarization, put forward rough solutions and improve the ability to use brains; on research level, students shall grasp the thinking mode to deal with macro and complicated situation and difficulties, cultivate and improve decisionmaking ability. They need schools to provide different posts and environment of practice.

\section{B. Practice-oriented Teaching Model Promotes Vocational Ability}

The academic circles have in-depth research on foreign successful teaching models of tourism such as Lausanne Mode in Switzerland, Cornell Mode in America. These successful cases pay attention to practical teaching without exception. Colleges have about 600 to 1,300 credit hours for practical requirements. For example, Cornell University School of Hotel Administration requires students to have 800 credit hours of internship. Tourism education in Britain pays special attention to practice, sets visiting class and "professional internship year", which not only strengthen students' understanding for classroom contents, but also promote their understanding for the work that they will perform in the future, improve their ability to find and solve problems. After graduation, with enhanced adaptive capacity and skilled business, they become professional talents that many tourism enterprises want to employ. These cases prove the important significance of practical teaching on the promotion of vocational ability.

Knowledge is equal to ability. Only through practice can knowledge turns into ability. Practical teaching not only helps to consolidate professional knowledge, but also helps to form vocational ability and establishment of correct professional attitude. Integrate learning process with working practice. In market survey and substituted post exercitation, it requires practical and realistic, diligent, firm and persistent, honest and faithful professional attitudes with exploration and innovation as well as teamwork. This kind of attitude also helps to promote vocational ability.

\section{PRoblems Existing In PRACTICAL TEACHING OF TOURISM MANAGEMENT MAJOR}

\section{A. The Orientation of Training Objective is Unpractical}

Training objective is the "training commitment" of schools for students and the industry. The higher the objective, the higher expectation of employers on the quality of talent cultivation will be. The orientation of training objective of many schools is "advanced specialized talents who work on management work". Curriculum provision, time allocation and teaching contents tend to the learning of management knowledge and management theory. Students hope to have the ability to become managers through four years of learning and keep a close watch on management position after graduation. Although now almost all schools emphasize the cultivation of applied talents and practical teaching and hope to train students' vocational ability in practical teaching, in reality, many schools don't pay enough attention to the management of practical teaching, put few fund in practical teaching, even without expenditure plan for this item. The pay for teachers who give practice guidance is far below the pay for teachers of theoretic teaching. These situations pass a kind of wrong information that "classroom learning is more important than practice" and better strengthen students" orientation of "senior managers in tourism enterprises". There is nothing wrong with this kind of pursuit. But as the foregoing statement, the senior management layer of tourism industry must be familiar with basic business. The high-level abilities in management, innovation, exploitation and planning mainly come from practice. In order to become senior managers, they need management knowledge. What's more, it is necessary to train the ability to handle accidents, problems and disputes and the innovation ability for product development, festival and special event planning.

\section{B. Teachers Have Poor Practical Ability}

Graduates of tourism management cannot conform to the standard of industry for compound-applied talents. It shows that there is something wrong with education, especially the educator. At present, teachers who work on undergraduate teaching of tourism major come from related discipline or postgraduates who work on teaching jobs upon graduation. Quite a number of professional teachers haven't practical experience, lack substantial relationship with tourism circle. It is impossible for them to meet the requirements of practical teaching.

In face of a variety of pressure of scientific research evaluation, it is difficult for teachers to carry out the promotion of practical ability. Besides, there isn't supporting policies and systems in schools. It restrains the enthusiasm of teachers to participate in professional practice to some extent, leads to the fact that teachers disconnect with the industry for a long time. They cannot update their knowledge in time and can only repeat what the book says. It is impossible for them to give correct demonstration and guidance for students.

\section{Poor Practice Conditions}

Laboratories in schools are mainly to train technical skills for professional post and carry out experiment teaching of professional courses and skill assessment. Generally speaking, it has simulative training room of tourist guide and training room of hotel service. It is an important basis to guarantee the effects of practical teaching. But because of the problem that the expenditure is limited, some schools haven't training rooms inside the school, or have poor training conditions, timeworn facilities and incomplete supporting facilities, or it is 
greatly different from real working scene. Students can only carry out very simple technical training. It is impossible to operate many combined training. The implementation of teaching plan cannot be in place. It cannot ensure the effect of practical teaching.

Off-campus practice bases include hotels, travel agencies and scenic spots. Students can directly participate in practical work and carry out substituted post exercitation with the identity of "prospective employees", which have very important significance on training students' vocational ability. But at present, the connection between colleges and tourism enterprises is not close enough. There are many problems existed in the operation. For example, enterprises only consider their requirements at present and don't provide the opportunity for students' work shift, which combat students' enthusiasm to enter the industry. The ability of enterprises to employ internship students is limited. The internship condition of many internship units discords and the internship contents are not unified. It also cause that the training of students' abilities is out-of-step. Besides, enterprises of internship cannot arrange internship mentors according to requirements. Or because of lacking incentive mechanism, internship mentors cannot give guidance carefully, which cause the loophole of vocational ability training.

\section{The Design of Practical Teaching Link is Unreasonable.}

The unreasonable design of practical teaching link mainly embodies in the following aspects: Firstly, it lacks consistency. The curriculum provision of undergraduate colleges related to tourism is almost the same. In the first year, they open common required courses and professional basic courses and hardly open practical course. Even thought they open practical course, the class hour is also relative scattered. Most centralized practice is in junior year or senior year in the form of substituted post exercitation. Because the professional practice guidance at earlier stage is inadequate, it is difficult for students to adapt to the internship position within a short time. It causes big psychological stress for them. They want to change profession before graduation. Secondly, the content lacks comprehensiveness and the training objective is not clear. The setting of internship and practical training in some colleges are excessively operational. Some follow higher vocational colleges to carry out single trainings such as training of tea art, training of room service, and training of catering services. There are few comprehensive practice courses. It doesn't help undergraduates to form comprehensive and systematic vocational ability. Students will be at a loss when they truly do practical work.

\section{E. Means and Standard of Practice Assessment is Unscientific}

Vocational ability embodies in practical work. Single proposition examination cannot test vocational ability. If the assessment is too simple and optional, students will also use casual attitude to treat practical teaching. At present, the assessment criterion of practical teaching is completely formulated by teachers who give practice guidance. The problems of teachers lead to the fact that the assessment criterion of practice is unscientific or difficult to implement scientifically.

\section{TAKE THE PROMOTION OF Vocational ABILITY AS THE CORE TO STRENGTHEN PRACTICAL TEACHING REFORM}

\section{A. Make Accurate Orientation, Strengthen Vocational Ability}

Applied tourism management undergraduate course cultivates "talents that face service industries, work on business operation and have the potential of managers" and cannot emphasizes that students are "middle and high ranking talented managers in tourism industry" after four years of college education when they leave school. It also forms obvious difference with theoretical research type of undergraduate course. Base on this training objective, establish course system by "taking vocational ability as the standard" and determine personnel training mode according to practical situation of the industry. Schools shall encourage teachers to work on practical teaching and carry out research and reform of practical teaching from system and mechanism.

It is very important that teachers shall have correct understanding of students. General application-oriented institutes have not very high marks to enroll students. Teachers have "prejudice" on students and haven't high expectation on cultivation of students' vocational ability. Understanding decides attitude. Attitude decides behavior. This kind of deviation of conception will cause deviations of teaching attitude and behavior. It is difficult to realize training objectives through reducing the difficulty of teaching. Improve teachers' correct understanding on students' vocational ability and strengthen the education on students' professional consciousness. With professional consciousness, students will have the power to enter tourism industry. Teachers shall continuously do occupational analysis when students learn this major and make students understand that tourism industry is the industry to serve people. Any management position shall have the ability to serve at basic level. Students will have career identity after receiving correct guidance.

\section{B. Strengthen Teaching Staff Construction, Guarantee Practical Teaching Quality}

The quality of teachers directly influences quality of teaching and talent cultivation. It is of vital importance to have teaching staff with practical experience to improve vocational ability of students. In many countries, it is necessary to have many years of industry background if colleges want to work on higher education in tourism. At the present stage, the higher education in tourism of our country cannot meet this requirement. But schools can start from the reform of personnel system and encourage existing teachers to walk out of the classroom to put on field practice, visit and investigate, receive systematic training in enterprise and obtain industry qualification certificate to become "double type" of teachers. They can also invite industry expert to enter the classroom to give lectures and train, make the contents of practical teaching become closer to reality of industry. Or let students enter enterprises. Schools and enterprises cooperate to develop "embedded" courses. Industry experts personally lead students 
to do practical training and internship, in order to realize seamless joint of vocational ability and market requirements.

\section{Increase Fund Investment and Construct Practice Bases inside and outside Campus}

Practice bases on and off campus are the necessary conditions of practical teaching. In simulative training environment, students can get familiar with professional post in the future in a short period of time, in order to rapidly adapt to the requirements of posts in the future. Therefore, schools shall increase input and invite tourism enterprises to participate in design and construct high-level Chinese restaurant, western restaurant, and guest room, information management laboratory of tour guide and travel agency and etiquette training room required by basic professional quality training.

Most training places in schools aim at training for operational position. Practice of higher level need to cooperate with tourism enterprises. It is the responsibility of enterprises to provide places for practice. As previously mentioned, posts corresponding to analytical practical teaching mainly include grass-roots management departments in various tourism enterprises, such as housekeeping department, banquet department, office in hotels, planning and allocation, external connection and market planning in travel agency, planning department and project department in scenic spot. Undergraduate education shall find stable practice base outside school that can meet the requirements and belong to this level. It can follow foreign higher educational institutions to establish guidance center of tourism practice especially responsible for professional internships and employment. It is necessary to attach importance to fund investment, so that it can win trust and good feeling of partners and also gradually obtain initiative and control power of construction of practice base.

\section{Strengthen Construction of Practical Teaching System}

There have been many successful cases of tourism teaching at home and abroad. It is essential to absorb experience of these schools, ensure the status of practical teaching, and guarantee adequate credit hours and credits. The practical system is well arranged. The curriculum provision is coherent. When constructing curriculum system, they should highlight the weight of practical teaching on credit hours and credits. The total class hours of all kinds of practical links in undergraduate education shall be not lower than 30 percent. For internship, practical training, substituted post exercitation and graduation field work, set distinct gradations to evenly distribute them in four years of learning and train students' vocational ability step by step. They shall invite specialized persons in tourism enterprise to participate in developing and designing items and contents of practice, in order to make them closest to industry requirements and job requirements.

\section{E. Reform Evaluation System of Practical Teaching}

The property of evaluation shall change from summative assessment to process assessment. The key points of evaluation shall change from school performance appraisal to capability evaluation. The way of evaluation can be diversified, such as practice report, short essay, interview, reply, skill competition, curriculum design and internship works. Some courses can integrate with professional qualification examination. Reforming from centering on one-sided, qualitative and subjective evaluation method to comprehensive, standard, qualitative and quantitative evaluation method can greatly improve the efficacy of practical teaching.

\section{REFERENCES}

[1] Zhang Min. Construction of Practical Teaching System of Tourism Management Major in Independent Colleges [J]. The Science Education Article Collects, 2013.

[2] Liu Yan. Exploration on Practical Teaching Reform of Tourism Management Major of Applied Undergraduate on the Basis of PARTS Strategy [J], Education and Vocation, 2014.

[3] Wu Xianfu. Research on Construction of "Vocational Undergraduate" Type of Practice Course System of Higher Education in Tourism [J], Modern Education Research, 2013. 